\title{
REPRESENTING SEXUALITY THROUGH FOLKLORE: EROTIC FOLKTALES AND ONLINE JOKES AS 'MIRRORS' OF GENDER HIERARCHIES
}

\author{
Aleksandar Takovski \\ Institute of Social Sciences and Humanities, Skopje, Macedonia \\ e-mail: aleksandar.takovski@isshs.edu.mk
}

\begin{abstract}
Gender roles, relations, and structures are aspects of human sexuality that are (re)constructed, negotiated, and even contested through a variety of discourses, including folklore. Erotic tales and sexual jokes are folk genres in which human sexuality is most explicitly presented. In this respect, the two key questions this study seeks to answer are: what kind of sexuality (gender roles, relations, and structures) is constructed through these genres and what inferences may be made about the society underpinning the discourse thus produced. To accomplish the ends, the study uses material collected from the Republic of Macedonia, organized in two data corpuses: erotic folktales and online sexual jokes. The content of the data is analyzed in order to identify the most reoccurring themes, gender roles, and relations constructed vis-à-vis the dominant motif in these narratives - the sexual intercourse, and thus to be able to describe the discourse on sexuality constructed by and through these genres, comment upon its social implications, and suggest way(s) of using it as a tool to counteract gender inequalities.
\end{abstract}

Keywords: erotic tales, folklore, function, gender differences, Macedonian folklore, online sexual jokes, representation, sexuality

\section{INTRODUCTION}

Human sexuality is a complex phenomenon related to and affecting multiple aspects of human social life, such as sexual intercourse, orientation and relationships, gender identities and relations, reproduction, family, marriage, birth control, etc. It is a phenomenon that actively constructs social identities, relations, structures, and practices along with the underlying views, beliefs, and values. At the same time, and even more importantly, it is a phenomenon that is constructed by various centers of power, such as the Monarch, the Church, and the State, who have recognized the role and the power of sexuality 
(Foucault 1978 [1976]) and have accordingly constructed various discourses (religious, political, economic, educational, cultural, artistic, etc.) in order to control sexuality and legitimize different political and economic ends.

Folklore, in this context, may not be the key instrument used to define and control sexuality, yet it is naive to believe that it is a mirror that reflects society either in its totality or in its consensual objectivity. The mere fact that folklore in the past was collected, selectively organized, presented, and used mostly by male collectors, ethnographers, and researchers, raises serious doubts regarding the potential gender perspectivization and gender-biased representation of sexuality through folklore. Folklore in this respect is only a fragmentary view of society, whereas erotic folklore in particular represents only certain types of sexual, and at the same time gender and social identities and relations, while foregrounding and/or omitting others. Social power structuration underlies such representations of sexuality which serve, I argue, to perpetuate male dominance, gender hierarchies, and specifically male views of society and sexuality.

In this respect, the two main research questions this study seeks to answer are: a) what kind of sexuality (gender identities, roles, and relations) is constructed through erotic folklore, and b) what inferences can be drawn about the society and its gender structures and hierarchies based on sexual discourse so produced.

To answer these questions, the study will first provide a theoretical overview of research ideas and findings related to three questions: a) What social functions of folklore can be related to sexuality? b) What kind of sexuality is constructed through erotic folktales on the one hand and sexual jokes on the other? c) What are the underpinning motives and purposes of such a construction? In the two sections following the literature review, I will present and analyze the data gathered and discuss the findings in relation to current literature. For the purposes of the study I used two data corpuses. The first consists of the English translations of 59 folk erotic tales collected by Macedonian folklorist Kiril Penushliski, translated by Slavists Gjorgji Mitrevski and Christina Kramer, ${ }^{1}$ and the second is comprised of 270 online erotic jokes collected from Macedonian most popular site for entertainment, www.vicoteka.mk, which contains the largest joke base in Macedonia. The contents of the tales and jokes were analyzed in order to first identify the most commonly occurring themes related to the key motif - sexual intercourse, and to be able to identify and categorize the sexual identities, roles, and relations of the protagonists in an attempt to (re) construct/exemplify the discourse on sexuality constructed through these texts.

The reason for choosing these two particular genres is twofold. Firstly, examples of sexual jokes from the period the erotic folktales were collected are unavailable. This could either point to the low level of popularity or even non- 
existence of the genre prior to the twentieth century, or to the lack of collected and preserved material. On the other hand, while the erotic folktale is a different genre than the joke, the time of their popularity and intensive circulation in society - namely before the twentieth century - gives and indispensable opportunity to gain an insight into the sexual mores and attitudes in a society much different than today's and thus to be able to draw some enlightening parallels and/or comparisons.

Finally, studying erotic folklore by means of these two particular genres seems to be a great challenge for understanding the social impact of the genres. In the absence of a detailed, documented account of the context of occurrence of erotic folktales (who, to whom, where, when, why, how), although there is a tacit agreement among researchers that such tales were usually told by men to a mixed, but mostly grown-up audience, it is difficult to draw any definite conclusions about the social functions of the tales, based on their textual analysis. The same may be said about online jokes that are usually accompanied by signs of appreciation (likes), yet no verbal or non-verbal reaction indicative of agreement, disagreement, protest, rejection, and the like. However, certain assumptions about the underpinning social hierarchies and dominant views and values as well as the social impact of erotic folklore may be made indirectly, by contextualizing research on folklore functions within the topic of sexuality. Therefore, I shall start the theoretical section with a very brief discussion on the functions of folklore in society and see how these relate to the genres concerned in order to shed light on the nature of erotic folklore as a vehicle of constructing, disseminating, and pre-treating sexual roles and relations.

\section{FOLKLORE, EROTIC TALES, AND SEXUAL JOKES}

\section{Functions of folklore and its relation to sexuality}

Developed under the influence of anthropology (Malinowski 1926; RadcliffeBrown 1952), one of the first to introduce the functional paradigm in the study of folklore was William Bascom (1954), who differentiated four functions of folklore. According to Bascom, folklore is a useful tool to educate children especially in non-literate societies, and to inculcate the customs and ethical standards to the young, while for the grownups it is a form of escapism, or in Bascom's own words, "folklore reveals man's frustrations and attempts to escape in fantasy from repressions imposed upon him by society, whether these repressions be sexual or otherwise" (ibid.: 343), which allows him to express thoughts or feelings that are not appropriate in everyday society. In addition, folklore also 
serves as an instrument that maintains "conformity to the accepted patterns of behavior" (ibid.: 346) through the application of social pressure and exercising of social control against individuals who attempt to deviate from social conventions. When this happens, Bascom argues, "a song of allusion, a proverb, a riddle or a folktale may be used to express disapproval" (ibid.). Lastly, folklore helps validate culture (and its social institutions, beliefs, and attitudes) in times when dissatisfaction with or skepticism towards an accepted pattern is expressed. Then, Bascom explains, usually a myth, a legend, an explanatory tale or a proverb is deployed to validate the pattern, thus settling down the dissatisfaction (ibid.: 344$){ }^{2}$

The transgressive nature of folklore has also been pointed out by Alan Dundes, for whom folklore "provides a socially sanctioned outlet for the expression of what cannot be articulated in more usual ways. It is precisely in jokes, folktales, folksongs, proverbs, children's games, gestures, etc. that anxieties can be vented" (2007: 275). Thus, "folklore can serve as a vehicle which requires an individual to do what he may not be permitted to do in everyday reality (e.g., in courtship games, complete strangers may kiss, in games of chase, acts of physical aggression are mandatory)" (Dundes 1966), thereby relieving the individual from assuming the responsibility (and guilt) for his or her actions (Dundes 2007: 60).

In terms of sexuality, it is easily conceivable how folklore can instruct younger generations into the proper, usually heteronormatizing discourse by offering them informative and didactic stories, inculcating them with acceptable norms of sexual behavior, or how it can offer grown-ups a world of fantasies inadmissible in reality, where they are not afraid to openly think and talk about sex, while at the same time using this folkloristic discourse for normative purposes to warn the adults who may potentially transgress the accepted norms.

While the assumption that folklore is a safe, unsanctioned outlet for the expression of culturally suppressed contents, forbidden desires, impulses, and fantasies is certainly true, doing so for the mere enjoyment or for the temporary sensation of liberation does not exhaust the social potential of folklore. If folklore is a symbolic reaction and reproduction of a culture and its sexual mores in this case, then the question is not only what kind of sexuality is reproduced through folklore, but what the end of it could be. Is it to perpetuate or challenge the socially dominant discourses on sexuality? To answer these questions, the next section will discuss erotic folklore focusing on the nature and role of the discourse on sexuality produced through erotic tales and sexual jokes. 


\section{Erotic folklore}

Although erotic folk material is available in many collections, starting from the earliest ones, such as Afanasyev's Russian Secret Tales (1966 [1872]), Krauss' Kryptadia (1883) and Antropophyteia (1904-1913), and many studies on erotic folklore have been produced, very few scholars tackle the question of the nature and role of sexual discourse produced through erotic folklore. Even the most popular name, when it comes to the study of sexual folklore, Gershon Legman, offers no committed socio-functional analysis or comprehensive understanding of sexual folklore. For Legman sexual folklore is a mechanism through which people "are projecting the endemic sexual fears, and problems, and defeats of their culture ... on certain standard comedy figures and situations, such as cuckoldry, seduction, impotence, homosexuality, castration, and disease, which are obviously not humorous at all" (Legman 1962: 201). All folklore, including humor, is an anxiety-releasing tool by which a joke teller sloughs off his fears by exposing the listener to the same fears and anxieties. In his opus magnum, Rationale of the Dirty Joke: An Analysis of Sexual Humor (1968), Legman provides a thorough taxonomy of sexual and scatological jokelore, but unfortunately falls short in producing a comprehensive and convincing functional and contextual analysis of the material. Instead, it seems that Legman is only highlighting the conceptual problems related to Freud's model, which he sets as his analytical framework. ${ }^{3}$ On the one hand, the model itself is psychological, rather than social, focusing on the anxiety-releasing function of humor, while on the other hand, Legman fails to accommodate the possibility that sexual humor may have other motives and ends beyond the release of anxiety and aggressive imposition of fear, such as assertion of superiority, imposing norms, creating interest, lubricating communication or merely having fun.

Studies of Slavic and South-Slavic erotic folklore are faced with similar challenges. While there are plenty of collections of erotic folklore (Terseglav 1981; Mrduljaš 1980; Krstanović 1984; Karadžić 1979; Vujkov 1990), and many scholars have studied different aspects of the material as various as the metaphoric aspects of erotic discourse in oral poetry (Pandurevic 2016), the function of laughter and carnivalization in popular erotic poetry (Karanović \& Jokić 2009), erotic connotations of cultural plants (Sikimić 2013), substitution of erotic with non-erotic language (Gura 2005), and manifestation of normal (women's and men's physical beauty, puberty, strength of libido, appropriate time for intercourse, etc.) versus abnormal (incest, manage a trois, gerontophilia, pedophilia, sodomy, etc.) sexuality (Kostic 1978), the question of sexual discourse constructed through folklore and its relation to society remains unanswered. 
The majority of the studies in the edited volume titled Erotsko $u$ folkloru Slovena: zbornik radova (Erotic in the Slavic Folklore) (2000) are dedicated to the tradition of collecting, organizing, and differentiating between genres, without revealing much or anything about the sexual roles, identities, and relations produced through erotic folklore, and their relations to society. Thus, these studies discuss a variety of folk erotic genres and aspects, such as the possibility to define (erotic) tongue twisters by the criteria of erotic elements present (Sikimić \& Otasević 2000), the distribution of themes of sexual humor per age groups (Miceva 2000), the recognition of erotic/eroticized proverbs (Grzybek 2000), self-distancing and norm-breaking principles underlying erotic jokes (Stanoev 2000), and other topics.

Although each study has a merit in its own right, it seems that only Ajdačić's study provides some insight into the gender-based hierarchies constructed through folklore. Studying the construction of the comic in the erotic folk tales, Ajdačić (2000) outlines three narrative instruments that underlie it: language, situation, and characters. Some of the linguistic forms and structures frequently deployed include: verbs that denote forceful movement, double language, and use of allegories and non-erotic expressions for erotic concepts and body parts, among others. In the analysis, Ajdačić notes that experienced, knowledgeable characters, usually males, use figurative language to lure inexperienced characters, usually females, into the act of love, thus highlighting one of the basic dichotomies present in the erotic narrative, the one between knowledge and lack of knowledge, between experience and inexperience. An interesting observation is that females are most often victims to experienced males, while males are victims to female adultery, an observation that is also valid for the material under consideration. In terms of functions of folklore, Ajdačić suggests that erotic folklore can educate the inexperienced by giving tips about sex life related to physiology, sexual morality, and pleasure, while at the same time criticizing lack of moderation, excess of lust or manifestation of other sex-related sins. Additionally, erotic folklore may be considered as a form of symbolic protest and revenge against the social hierarchy and injustice, especially manifested in the narratives where a poor male character lures a rich man's wife into a sexual intercourse. Finally, a good observation by Ajdačić is that women are portrayed negatively in the erotic folklore due to the fact that "tales depict a male's image of the world, both of the teller and the collector" (2000: 501).

Ajdačić's observation that folk tales are misogynist pieces of folk expression is also confirmed by Lövkrona's study (1998) of the construction of gender, gender differences, and hierarchies in the erotic narratives produced in premodern Sweden, in which the author argues that the politics of erotic folklore served to legitimize and sustain male power structures. Lövkrona's analysis of the theme, 
plot structure, and voice constructed in the narratives, intended to uncover power relations between the actors in the story, but also the gender roles, relations, and hierarchies in society, reveals two different types of masculinities and femininities involved. Positive masculinity is represented by a young unmarried man, a man who is potent, smart, and always ready to seduce, while positive femininity is manifested by the young, unmarried, sexually innocent, but willing woman. The incarnation of the negative masculinity, according to Lövkrona, is a male character who fails to satisfy or seduce a woman, as well as a man who is impotent and sexually inexperienced. Negative femininity, on the other hand, is represented by women who are wanton, lewd, sexually insatiable, and who take sexual initiative: women who clearly represent a threat to masculinity.

Related to this last type of femininity is Lövkrona's argumentation that although men are those who provide models for the interpretation of reality in patriarchal societies, women have accepted these models, but have additionally created their own, alternative meanings, sort of "oppositional reading" (Hall 1980) of the narrative, with an embedded "hidden transcript" (Scott 1990). This is made possible through the identification with the position of negative femininity, which is also a position of independence and resistance, and insubordination to the male, patriarchal expectations of women. Identifying with females who were lewd and sexually active but strong and independent at the same time, Lövkrona argues, empowered women by offering them the power and scope for agency. The symbolic nature of this subversive strategy notwithstanding, it is hard to believe that the possibility to identify with independent female characters who pose a threat to masculinity and thus ridicule males' hierarchies, has really affected the female members of the folk audience beyond the momentary sigh of relief.

Finally, Macedonian erotic folklore is preserved in several collections, such as those by Cepenkov (2007) Penushliski (1989), Velichkovski (1989), Smilevski (1993), Risteski (1994), and others, and has been studied by a few scholars, most recently Martinoska (2007) and Pilichkova (2009). In a fashion similar to Ajdačić, Pilichkova (2009) highlights the role of humor as a basic aesthetic building block of the erotic folklore. Although not going into a fully-fledged humor analysis of the material, Pilichkova offers a thematic classification of the material, listing several categories, among which are: anticlerical tales ridiculing the sexual advancements of dishonest priests and hodjas ${ }^{4}$ being punished for their misbehavior, instrumental, clever substitution of erotic with non-erotic language, ambiguous sexual expressions, sex used as an instrument of vengeance (e.g. to the infidel priest), a jealous husband being outsmarted by a woman through a sexual intercourse (sex as educational tool), adulterous women, and, identically to Ajdačić, the experienced/inexperienced dichotomy, 
where innocent girls fall prey to experienced men, and naïve husbands are victims of adulterous wives. Although not engaging in a social analysis of the erotic folktale, Pilichkova concludes that erotic folklore is used to ridicule the imperfections of certain individuals or professions.

\section{Sexual jokes}

While many sexual jokes tend to perpetuate socially constructed stereotypes of certain groups of people, as is the case with the physically attractive blondes, or oversexed, adulterous French women (Davies 2011), there is also a significant corpus of jokes that challenge patriarchal hierarchies and criticize dominant constructions of femininity as pointed out by Lövkrona (1998). Such line of argumentation is a significant step forward from the previous ideas about the nature of sexual humor dominated by the Freudian concept of sexual jokes. According to Freud (1960 [1905]), jokes allow the expression of forbidden, suppressed, and unconscious aggressive and sexual impulses and desires arising from the id by circumventing the censorship of the superego through a clever joke technique, thus allowing gratification of the libidinal impulses, and enabling a discharge of superfluous nervous energy through laughter. Thus, jokes allow people to experience for a moment the illicit pleasure derived from releasing some of our primitive sexual and aggressive impulses. This presupposes that people who suppress these impulses most would feel the greatest pleasure arising from the release of nervous energy, and enjoy the sexual jokes most - an assumption that empirical research has falsified on many occasions (Levine \& Redlich 1955; Kline 1977; Ruch \& Köhler 1998). The relief function of jokes notwithstanding, more recent studies of feminist humor have elaborated on the manners in which such humor challenges traditional views of gender by targeting men, resists dominant constructions of femininity, as well as opposes gender inequalities and hegemonies in a patriarchal society with an aspiration to reform it (Crawford 1995, 2003; Franzini 1996). In a study on lesbian humor, Bing and Heller (2003) show how sexual humor can challenge dominant culture and its definitions and presuppositions about lesbianism. The authors demonstrate how lesbian jokes help lesbians construct and negotiate (homo)sexual identities as an empowering mechanism which through transformation, resistance, and subversion challenges dominant views and presuppositions. In a more recent study conducted among Bahrein women, Reichenbach (2015) shows how these women who are expected to be respectful of the societal images (gender ideals) and expectations of females as self-controlled, restraining, obedient housewives not permitted to laugh publicly, use humor to resist, challenge, and criticize 
gender identities and patriarchal hierarchies. It is through humor that these women achieved liberation from the pressures and constraints of the patriarchal society and coped with its gender inequalities and absurdity.

While it is certain that sexual/feminist humor can definitely challenge gender hierarchies, it is hard to tell whether sexual/feminist jokes may bring any social change, especially in societies where such narratives are being circulated in the safe zone of the closest relatives and friends (e.g. Bahrein). On the other hand, the public exposure of such material in more liberal, democratic societies may not only help social groups to more freely communicate their sexual identities but, by drawing the attention of the audience, it may also attract sympathy and even support. This, however, is only possible as a result of the interplay of several socio-political practices, public joking being just one of them.

\section{DATA AND METHODOLOGY}

Given the absence of contextual data on the material under investigation (Macedonian erotic folktales and erotic online jokes), examination of the erotic folklore potential to resist or even challenge gender-biased presuppositions and hierarchies in a communicative context is almost an impossible mission. However, a qualitative textual analysis of the material can construct a comprehensive image of the discourses of sexuality, upon which to draw inferences and provide plausible explanations of the gender relations, structures, and hierarchies embedded in and represented by these discourses.

To accomplish these ends, two data corpuses were used: the English translations of 59 folk erotic tales collected by Macedonian folklorist Kiril Penushliski, ${ }^{5}$ and 270 online erotic jokes, posted in the period from 26 September 2006 to 19 February 2018 in the erotic jokes section of the site vicoteka.mk, Macedonian most popular site for entertainment, containing the largest joke base in Macedonia. ${ }^{6}$ Using the data, the analysis seeks to identify: a) the most common themes present in the material, and b) the most common gender roles and relations vis-à-vis the dominant motive of sexual intercourse.

The process of identification of the main themes was relatively easy, given that some of the titles of the tales and jokes either directly revealed the subject matter of the narrative, as in "A wife can't be guarded", which unambiguously set the expectation of a story about an adulterous wife, or the title pointed to the main characters around which the theme of sexuality was developed, as is the case with the tale titled "The young man, the lady, and the servant". The text structure of the title hints that the plot evolves between a young man, who is either inexperienced or cunning, and a rich (either experienced or naïve) 
lady. The classification of the themes of the jokes was based either on the title (e.g. "The lover") or the punch line that revealed the key topic. The procedures of identifying the main themes, rather than their applications, were doublechecked by a colleague, and provided almost identical results, at times only in a different wording, for example, "unfaithful wife" instead of "adulterous".

\section{Erotic folktales}

The analysis of the folktale narratives reveals that the most frequent themes of the narratives in the order of their frequency (from high to low as shown in the brackets) are: a) sex as an end in itself $(n=16)$; b) sex as a tool of punishment $(n=14)$; c) other (29): male's oversized genitalia $(n=3)$, sex as a tool of juvenilization of older women $(n=2)$, impotence of old men $(n=2)$, sex as an instrument of material gain $(n=2)$, women's excesses of sexual desire $(n=2)$.

Regarding the most dominant motif of staging a sexual intercourse motivated by desire, in most of the tales bearing this motif it is men who are the initiators or the plotters of the act $(n=10)$. In these tales, men are most often presented as young, confident and potent seducers, who succeed in luring young and inexperienced women into the act of lovemaking by a witty design accomplished either through language or a cunning plan. Thus, in the tales titled "The grain gatherer" and “The priest's daughter who didn't want to get married”, the unwilling and unyielding young girls are lured into sexual intercourse by clever young men who use non-sexual language (grain gatherer, scratcher) for sexual body parts, most often for male genitalia (penis), to trick the inexperienced girls into having sex with them. The usual victims of such kind of language censorship, intended to disguise the true nature of the intentions, are peasant girls, priests' daughters, kings' daughters or even the queen herself. In the tale "The king's widow and the clever servant", the queen forbids the use of obscene language, but is seduced by a young peasant who substitutes all such expressions with the ones referring to elements of nature, such as heavenly fruits (tits), meadow (pubic area), spring (vagina), horse (penis), and saddle bags (testicles). Another strategy, in addition to language, deployed by men intending to trick women into sexual intercourse is to present sex as a solution to a grave, even fatal problem like death or the plague. Thus, in the tale "He spoke with the lord", the sister-in-law agrees to have sex with her brother-in-law as the latter pretends to be on his deathbed. Using the situation and his sister-in-law's empathy, but also her naiveté, he convinces her to have sex with him by presenting the act as God's will that will help him cure. The deployment of the same 'sex as cure' strategy occurs with a much lower frequency in narratives where women are presented in the capacity of initiators of sexual intercourse $(n=4)$, 
as in "Oh mercy I am dying for grapes", or "The cornel cherry salesman". What seems intriguing in this respect is that women are never, or at least not in the present corpus, presented as using language as an instrument of seduction. Instead, women use language as a strategic tool to cover for the infidelity, as in "Feminine wiliness", where the unfaithful wife makes up a whole story to accomplish the end.

The second most frequent motif is that of female's infidelity, which, against any expectations to be criticized and condemned, is very much acceptable since females' unfaithfulness is represented as a consequence of, and often a revenge for, the husbands' mistreatment, misbehavior, and adultery. Often women are pushed into committing adultery as a result of their husband's excess of confidence or jealous overprotection, manifested in forbidding the wife to socialize or even to leave the house. In many of the narratives bearing this motif, the husband is a priest, a hodja or a rich man, which adds a tone of social criticism to the class of high-status men, presenting them as an incarnation of the will for power and complete control. In three of the tales, the wife's infidelity is a result of the husband's verbal insults, in regard to which the 'crooked cunt' motif is the most frequent one. In these narratives, the husband makes fun of the wife's allegedly deformed genitalia (crooked cunt), so she seeks solution for the problem through a sexual intercourse with another man, usually a craftsman with the alleged skill of straightening vaginas. Finally, the wife's adultery is also a counter-reaction to the husband's infidelity. As a leitmotif, spousal infidelity is intriguing in two aspects. First, female's infidelity is carried out openly; the women who have sex outside marriage admit having it as a retribution, intended as a punishment for their husband's adultery. Differently than this, the cheated husbands actually trick their own unfaithful wives into believing that they (the wives) have sex with another man, while they actually have sex with their own husbands disguised as other men. Thus, men in these narratives change their appearance, disguise themselves as desired lovers, not only to get back at their unfaithful wives, but to also teach the adulterous wives a lesson, while at the same time to remain faithful, and unlike women, in their retribution, they remain sinless.

Another interesting motif present in the narratives is the use of sex as a medium of competition and material gain, as in the tale titled "The young man, the lady, and the servant", in which a young man's sexual prowess and trickery brings him a great deal of material gain (land, cattle, money) offered by the lady as a challenge to test his sexual potency and will. Other motifs present in the narratives once or twice include oversized male genitalia, old men's sexual impotence and sexual nostalgia, old women's desire to feel the thrill 
of physical love again, a man being scared of his wife's excess of sexual desire which is tamed by a trick, and physical punishment for the husband's infidelity.

\section{Jokes}

Although classifying a corpus of 275 jokes is both a menial and impossible task, given the variety of themes present as well as the subjectivity of the coder, some tentative categories may be defined, based on the aspect of sexual intercourse that is foregrounded (also functioning as a base for the punch line), and on the identity and relationship between the key protagonists.

\section{Women's infidelity, promiscuity, and sex urge}

One of the most reoccurring motifs in the jokes analyzed is that of females' sexual agency, manifested through spousal infidelity $(n=29)$, promiscuity $(n=27)$, and sex urge $(n=14)$. Some of the jokes manifesting female script simply illustrate the act:

Two friends are talking.

"Do you tell your husband each time you have an orgasm?"

"No way, he specifically told me not to disturb him while he is at work."

Other jokes carry more moralistic overtones by setting the husband as part of the narrative, in which he is usually presented as a naïve victim being mocked either by his wife or the lover:

A worker calls the office, explaining that he does not feel well and will not come to work. The boss says:

"When I feel down, I get on my wife, and after an hour I am as good as new, coming to work fresh as mountain dew."

After an hour the worker comes in. And the boss asks him how he is satisfied with the tip. The worker says:

"You are right, boss, the tip works miracles, especially with your wife beneath."

The second most frequent sexual behavior assigned to women in jokes is that of promiscuity $(n=15)$ :

After a great night, the guy asks the girl how many partners she has had before him. She is angry but starts to count. After three hours, the guy says: "I am sorry to have asked you this, I shouldn't have." 
She quickly replies:

"Oh, shut up, I am still counting."

or,

A woman complains to the doctor that she is hard to satisfy. The doctor recommends her to try it with two partners, to which she replies that she has already tried it. Then the doctor recommends she tries with five or even ten men, to which she replies she has done it already. The surprised doctor says:

"You are a medical phenomenon, my dear," and the woman replies:

"Exactly, my doctor, a phenomenon! Not a whore like everyone else thinks."

Very often promiscuous behavior is assigned to stereotypical professions, such as secretaries, nurses, and the demographic group of blondes $(n=12)$, while the jokes in which money is the motivation or the purpose of the intercourse very often include women as beneficiaries of material gain, although they are usually tricked and often humiliated by men $(n=9)$. Unlike erotic folktales, jokes do present women as openly talking about sexual fantasies and desires:

An American, a French, and a Macedonian female student were talking about what each of them wanted to be.

The American: "I want to be an oil field, so they would drill me...drill me."

The French: "I want to be an ice cream, so they would lick me...lick me."

The Macedonian: "I want to be a Faculty of Electric Engineering so they would finish with me in seven years."

\section{Men's lack of potency, interest, and underperformance}

As compared to similar representations involving male characters, there are a few differences. While men are also represented as unfaithful and promiscuous, although to a noticeably lesser extent, there is no male profession typically related to excessive sexual activity, nor is there a narrative in which males are lured into having sex for money, and, above all, there are no jokes in which men freely express their sexual fantasies. Moreover, the most frequent capacity men are represented in $(n=21)$ is the lack of sexual potency, interest, self-confidence, often underperforming - all types of behavior frequently being made fun of. The two following jokes illustrate some of the arguments:

When having sex, the wife tells her husband that he is like a mobile phone. Hearing this, the husband asks: 
"Is it because I vibrate well and make you excited?"

"No, it is because you lose the signal in the tunnel," the wife replies.

Two neighbors are talking. One of them says:

"Me and my husband, we have Olympic sex."

"Good for you, this means you have great sex," says the other.

"No, it means we have it every four years."

There is an obvious reason for ridiculing males' sexual underachievement, and this clearly emphasizes the social expectation of men to be sexually potent. The assumption that jokes favor males' views, attitudes, and even anxieties typical of patriarchal societies can also be inferred from jokes on the topic of men's unfaithfulness $(n=7)$. What is peculiar about these jokes is the focus on the act of adultery itself, rather than on the perception or even involvement of the cheated wife. In these narratives, the wife is frequently only implied, talked about, and even if she physically witnesses the act of adultery she is voiceless; as such she cannot evoke the sympathy of the audience as an innocent victim, as is the case with female adultery discovered by men. The following examples illustrate some of these arguments.

"Do you look into your wife's eyes while having sex?"

"I did once."

"How was it?"

"A disaster, it happened when she was walking into the bedroom."

"My father is a real coward," says a first-grader to another, and adds, "Each time mom is not at home, he is afraid to sleep alone and goes to the neighbor."

The second example is interesting from two aspects. First, it constructs male infidelity though a third-person narration, in this case a male child. By creating a narrative distance between the narrator (boy) and the action presented (father's adultery), it also potentially creates a moral distance, or at least it mitigates the potential effect - scorn by the audience. On the other hand, there is no example in which a little girl reveals a parent's sexual misconduct.

\section{Homosexuality}

Another notable difference between male and female characters in terms of their representation in sexual jokes is related to the issues of homosexuality and transsexuality - two aspects not found in erotic folktales. What is notable here is the manner in which male homosexuality $(n=9)$ is presented as a laughing 
stock, a completely innocent, non-threatening behavior, sort of de-masculinized phenomenon. The focal point of jokes on male homosexuals is their craving for anal sex as shown in the following two jokes:

A gay hadn't had sex for a while. After checking that there was no phallicshaped vegetable in the fridge, he went to the butcher's and ordered the biggest sausage. The butcher started chopping it into slices. Seeing this the gay shouted: "Hold on, honey, with that chopping. What do I look like to you, a jukebox?"

Two gays were crossing a river when one said: "I think that a fish just came up my anus." The other replied: "Keep going, is not a fish."

Unlike this mild ridicule of male's homosexual habits, female homosexuality is either defined vis-a-vis male as in "What do two lesbians sing after sex? All is the same save he is not around" or in gross manners as in "Why did the lesbian version of Cinderella die? During sex, her vibrator turned into a pumpkin”.

Finally, another significant difference related to transsexuality is that in all the three jokes on the issue of transgender / changed gender, it is a man who has become a woman, and thus it is a man who has sex with another man, thus becoming the butt of the joke, but it is never the other way round, a woman turning into a man having sex with a woman.

\section{Younger and older generations}

Other joke categories indicative of gender differences are: jokes about young generations who are either sexually more mature or have different sexual mores and ideas that usually shock the parents $(n=8)$, jokes about children who are knowledgeable about sex $(n=5)$, and jokes about older generations who lament over the loss of their sexual aptness or capitalize on an opportunity offered $(\mathrm{n}=10)$.

The most frequent parent-child relationship in the first category is that between a mother and daughter who, instead of learning something new about sex or proper sexual conduct, surprises the mother with an unexpected line of thought as demonstrated in the following joke:

A mother is teaching her daughter:

"In the moment of temptation, ask yourself whether an hour of pleasure is worth living a life of shame."

"Mom! You should tell me how you managed to make the pleasure last for an hour." 
While the usual pair in these educational jokes, in which sexual knowledge is intended to be passed from one generation to the other, is mother-daughter (female-female), the typical pair in the jokes in which the child demonstrates sexual awareness and knowledge untypical of the age is usually that of a father or a teacher and always a male child. Intriguingly, on the other side of the age spectrum, the old age, in many of the jokes it is mostly old women who are represented as lamenting over lost sexual powers or are eager to seize any opportunity that presents itself, even if it is presented as a punishment or a threat as in the following example:

A granny was flying on a plane where there were terrorists who demanded that each passenger should undress from the waist up. The granny asked: "Does everyone have to do this?"

"Yes," answered the terrorists, who then demanded that everyone undresses from the waist down so the terrorists would fuck them. Then a blonde asked:

"Do we all have to do that?" to which the granny replied:

"Shut up and do as you are told."

\section{Incongruous representation of sex}

Finally, the most numerous category of jokes is comprised of those that present and highlight an incongruous, and thus humorous, aspect of sexual intercourse, or an implication of it.

A man and a woman were making love. The woman got very excited and started shouting: "Tell me something dirty!" To which the man said: "Kitchen, bathroom, bedroom..."

Often there is a misinterpretation, a pun or a witty comment involved:

A man and a woman were making love, and the man says: "A bit down, now a bit up, ...wait, wait, give it to the right, now move a bit to the left..." To what the woman asks: "Sorry, my dear, do you plan to fuck me or park me?"

There are plenty of other themes that can be recognized in this large category, but with the focus on the incongruous perception and/or presentation of the sexual act, these jokes reveal little, if anything, about gender roles and relations. 


\section{DISCUSSION}

Although it is difficult to ascribe a definite educational value (Bascom 1954; Ajdačić 2000) to the folktales presented, especially in light of the absence of contextual data, they do confirm many of the current research findings discussed earlier. First, the majority of the tales highlight the existence of the experienceinexperience dichotomy precisely as discussed by Ajdačić (2000) and Pilichkova (2009) - a dichotomy in which an experienced, usually young man seduces an inexperienced woman by the use of figurative, goal-oriented language. Making these two characters the bearers of the leitmotif additionally corroborates the models of positive masculinity (potent, young, experienced) and positive femininity (inexperienced, young, unmarried, sexually innocent woman) as outlined by Lövkrona (1998). In addition, the same material provides evidence of the argument that sexual folklore expresses forbidden contents, while at the same time it projects fears and anxieties. Although not many in number, the tales which I have labelled "sex as a cure" are actually narratives in which free, uncensored, and unfettered expression of female sexual desire comes out in the open. Although veiled in a witty narrative design in which the desire for sex is substituted with a desire for cherries or grapes, these stories allow a taboo topic - that of women's sexual appetite - made unambiguous with the reference to food, to transgress the watchful eye of the society and be freely expressed. The same claim is equally applicable to the tales in which women openly commit adultery, even admitting it. In addition, in the group of tales in which adultery is a weapon of vengeance against the mistreating, jealous husband, one can easily recognize the presence of the symbolic fear of castration, or even impotence of the husband who is unable to treat his wife properly. The purpose of these narratives may be twofold: on the one hand to project the male's fear of being cheated on, allowing the expression of this fear, while on the other, by putting the man's weakness, flaw in character, to a public ridicule, to warn husbands of the possible outcome of their mistreatment and thus make them conform to patterns of accepted behavior. It is exactly through a story, as maintained by Bascom, that the society intends to express disapproval, to warn and even criticize (Bascom 1954). The role of criticism, as far as the present corpus goes, is highlighted especially in the tales that Pilichkova (2009) terms as anticlerical. The difference, however, as compared to the present material, is that the anticlerical tales Pilichkova writes about are critical of the priests' sexually improper behavior, and an excess of lust as phrased by Ajdačić (2000), while the improper behavior of the priests in the present material is caused by their will to have excessive control over their young wives. In this context, the act of adultery is symbolically not only a criticism of the rigidity and the will for power of the clerical cast, but also a free expression of sexual desire. 
Regarding the sexual roles, relations, and structures constructed through the tales, the existence of the experience-inexperience dichotomy in which men are the seducers and women merely a game in the play of seduction worked out through figurative language, points to a sexual relationship in which men are portrayed as both sexually prowess, cunning, and active sexual agents, while women are deprived of the opportunity to act as agents of sexual behavior, and their image as sex objects is highlighted instead.

Ironically, a woman can be a subject of sexual engagement, and even an initiator of it, only through the act of adultery. It is only through unfaithfulness that she can initiate and achieve gratification of her desires. But even then, the end of such sinful gratification is not to satisfy her own desires and fantasies but rather to serve as a didactic and moralizing instrument of retaliation for the misbehaving husband. The act of adultery is thus presented in a framework in which the act is legitimized and allowed to happen because it is a just punishment, which many of the narratives confirm through the husband's end lines, acknowledging his own misdoing with the words "It served me well!". Without doubt, this carries an implied warning to all males in the audience that their own misconduct may be sanctioned in a similar manner. The narrative then is not about female sexual freedom, agency or opportunity to act out of one's own will, but rather a moralizing political tool of keeping men well-behaved, and thus preserve conformity to proper, accepted behavior.

While research has identified many cases in which sexual jokes are a means of female empowerment against the patriarchic society and the fixed, maleconstructed gender roles and hierarchies it imposes on women (Crawford 1995; Franzini 1996; Bing \& Heller 2003; Reichenbach 2015), the jokes analyzed here mostly evidence their psychological function as an outlet that allows free expression of repressed, forbidden sexual impulses. Additionally, the analysis of the sexual jokes suggests that these particular examples work more as means of subordination and disempowerment of women, rather than tools of resistance to and challenge of male structured gender hierarchies.

One of the dominant images of the women present in this corpus is that of an adulterous, promiscuous character who freely speaks about her sexual urges and fantasies. Such a speech may confirm Freud's concept of jokes as free expressions of socially suppressed, forbidden impulses, but the representation of women as bearers of immoral behavior, manifested through adultery and promiscuity, shows that there is much more involved in this particular representation than meets the eye. The image of the woman as unfaithful and promiscuous can be taken as an index of modern-day society and its sexual mores, anxieties, and hypocrisy. The difference in the representation of the two genders, as related to the themes of adultery, promiscuity, and libidinal 
drives, is intriguing to say the least. Firstly, the frequency of the occurrence of the theme 'wife's infidelity and promiscuity' in the jokes $(n=72)$ is much higher than the frequency of the same motif as related to men $(n=12)$. The quantitative misbalance in the representation may suggest that women are morally frail, immoral, unable to resist a temptation. More importantly, their infidelity and lack of remorse are represented as a merciless act, since sexual intercourse for them is an end in itself and not a didactic, moralizing instrument as is the case with the folktales. Contrary to this image of the wife as an untamable shrew, the husband is an innocent victim of adultery, often represented sympathetically as a fool, a naïve husband believing his wife. Another astonishing aspect related to the construction of genders, concerned with the motif of adultery, is the presence/absence of the cheated partner. In the jokes in which men are unfaithful, the cheated spouse is implied, talked about in the narrative, but very rarely, if ever, physically present in the act of the adultery. Differently than this, in the jokes where women commit adultery, they are very often caught red-handed. The cheated husband is an eye-witness whose presence is offered for a laugh or sympathy by the male audience. Moreover, the representation of the male's infidelity is mitigated, made socially more acceptable either by being narrated through a male child perspective or through a verbal pun. Generally, there is a perverted logic in representing women as unfaithful and promiscuous, while men are naïve, sympathetic victims, especially in light of the fact that in modern-day societies it is men who tend to be more promiscuous and unfaithful. Yet the humorous narratives create an opaque world turned upside down. The reason for doing so, I believe, is the intention to discipline women by presenting them negatively as social deviants (unfaithful and promiscuous) in order to be symbolically tamed and punished through ridicule. This logic, however, seems to potentially have another motive, and that is to alleviate and purify men from the sins committed in the real world. The imaginary world of the joke, in which women are unfaithful and men are innocent victims, offers a denial of responsibility for the acts committed in the world where men are far more sexually promiscuous and unfaithful. As such, these jokes could potentially function as a collective therapy for men to alleviate their guilt, and gain moral, although imagined, superiority over women.

Condemnation and fear of sexually active women, even in the imaginary joke world, also underlies one of the key male fears as represented in the jokes about men's impotence, and that is the fear of castration. In all of these jokes men are being made fun of for not being able to satisfy their partners, thus alluding to the socially constructed ideal of a man as potent, uncompromisingly willing sexual actor, an ideal that is typically masculine and masculinizing, which can also be observed in the manner homosexuality is constructed. Male homosexuality 
is acknowledged, is made fun of, and detested for its unnatural nature that goes against God's design (Davies 2011), but also rejected because penetration means being dominated, something inadmissible for men. At the same time, the attitudes on female homosexuality are harsher, creating repulsive images like a vibrator turning into a pumpkin in the female vagina, as constructed in the joke shown above (section Homosexuality), as if it is both unimaginable and inadmissible for women to be anything but heterosexuals. The image also speaks of a male view in the sense that while male homosexuality is unacceptable, women's is unimaginable. Additionally, the non-existence of examples of womento-men sex transition may serve as a proof of the attitude that such a transition is unimaginable as well, and hence unacceptable, implying that one becomes a man only by birth (naturally), and not through surgery.

Finally, the sexual discourse constructed through folktales further confirms the existent findings and, surprisingly, looks more democratic. On the one hand, such discourse favors male ideals of femininity (unmarried and inexperienced) and masculinity (experienced, smart) and deprives women of sexual agency, making them objects of sexual actions. On the other, it gives women the right to openly express sexual desire, albeit metaphorically, by reference to appetite for food, but more importantly the engagement in illicit, adulterous intercourse; ironically, it is a means of women's empowerment by which they want to make disobedient men conform to acceptable patterns of behavior, and to discipline them. Sex for these women is an enjoyment, but also a means to keep some balance in society.

Differently than this, sexuality constructed through jokes is more poignantly reflective of masculine views and attitudes, of patriarchally conceived, organized, and represented gender roles and relations. What is more interesting is that this discourse is not a mirror held up to society but more a male's perverted fantasy projected upon it. The material depicts a world in which women's sexual agency is attributed as deviant (unfaithful, promiscuous, and lustful) and needs to be sanctioned through ridicule. Conversely, the man's deviant behavior is mitigated, he is reminded that he needs to uphold the socially constructed image of him as a sexually potent figure, which at the same time projects men's greatest anxiety - sexual underperformance. By taming and punishing females' sexual appetite and behavior and ridiculing men's sexual underachievement, the jokes seem to be working towards the same end - the re-assertion of males' sexual dominance and females' subordination, even if in imaginary form. Even jokes about homosexuality and sex education confirm that the relation manwoman is not one of equality but of asymmetry. 


\section{CONCLUSION}

While the textual analysis of the sexuality constructed in erotic tales confirmed some of the existent and already studied gender inequalities constructed through the genre of folktales, it also revealed a moralizing social potential of tales to at least flag, if not sanction, the improper behavior by some groups of people, in this case priests and mistreating husbands. The woman in the folktales may be inexperienced, lustful, even empathetically reprimandable, but she is far from the Babylonian whore, the image constructed in the world of jokes. While we are not able to remedy any of the potential negative social effects that the discourse of sexuality produced by folktales may have caused, it is both possible and urgent to undertake the challenge of fighting against the gross stereotype about women, constructed by means of the jokes. While contextually studying the use of such jokes in a conversational context may point to actual motives, ends, and reception(s) of the stereotypes, the introduction of the genre in contexts where the samples may be offered to the attention, inspection, and mostly critical examination of the audience, is a more poignant method of fighting this injustice. Education that aims to promote critical thinking and gender equality can be one of such contexts. After all, the idea of using folklore as a didactic tool is far from being new (see Dundes 2007), yet exposing gender-biased hierarchies to pupils is both novel and necessary.

\section{NOTES}

1 See http://www.pelister.org/folklore/erotic_folktales/index.html.

2 The four functions Bascom speaks of are eventually reduced to one, Sims and Stephens (2005: 176) argue - that of maintaining the stability of culture. Although the functions of education, maintaining conformity, and validating culture directly relate to its maintenance, it is worth noting that escapism may have a conservative function that allows members to vent out the dissatisfaction caused by the culture's institutions and conventions, but it may also have a subversive function of, at least symbolically, challenging the same institutions in hope for a change.

3 For a fully-fledged criticism see Oring (1977).

4 A teacher in Islam.

5 See http://www.pelister.org/folklore/erotic_folktales/index.html.

6 See www.vicoteka.mk.

7 The punch line and its understanding rely on the cultural knowledge, actually an urban legend, that it takes approximately seven years for the students of Faculty of Electric Engineering to finish their studies. At the same time the punch line draws 
on the polysemy of the word "finish", which can refer to the ending of an action (as in "finish the studies") as well as to the act of male ejaculation.

\section{REFERENCES}

Afanasyev, Aleksandr 1966 [1872]. Russian Secret Tales: Bawdy Folktales of Old Russia. Baltimore: Clearfield.

Ajdačić, Dejan 2000. O smjesnom i o moralizmu u erotskim pricama. [On the Laughable and the Moralizing in the Erotic Tales.] In: D. Ajdačić (ed.) Erotsko u folkloru Slovena: Zbornik radova. [The Erotic in the Folklore of the Slavs.] Belgrade: Stubovi kulture, pp. 474-506.

Bascom, William R. 1954. Four Functions of Folklore. The Journal of American Folklore, Vol. 67, No. 266, pp. 333-349. http://dx.doi.org/10.2307/536411.

Bing, Janet \& Heller, Dana 2003. How Many Lesbians Does It Take to Screw in a Light Bulb? Humor: International Journal of Humor Research, Vol. 16, No. 2, pp. 157182. http://dx.doi.org/10.1515/humr.2003.009.

Cepenkov 2007 = Tsepenkov, Marko. Erotski prikazni. [Erotic Tales.] Skopje: Feniks. Crawford, Mary 1995. Talking Difference: On Gender and Language. London: SAGE.

Crawford, Mary 2003. Gender and Humor in Social Context. Journal of Pragmatics, Vol. 35, No. 9, pp. 1413-1430. http://dx.doi.org/10.1016/S0378-2166(02)00183-2.

Davies, Christie 2011. Jokes and Targets. Bloomington, Indiana: Indiana University Press.

Dundes, Alan 1966. The American Concept of Folklore. Journal of the Folklore Institute, Vol. 3, No. 3, pp. 226-249. http://dx.doi.org/10.2307/3813799.

Dundes, Alan 2007. The Meaning of Folklore: The Analytical Essays of Alan Dundes. Edited by Simon J. Bronner. Logan, Utah: Utah State University Press. DOI: 10.2307/j.ctt4cgrzn.

Franzini, Louis R. 1996. Feminism and Women's Sense of Humor. Sex Roles, Vol. 35, No. 11/12, pp. 811-819. https://doi.org/10.1007/BF01544094.

Freud, Sigmund 1960 [1905]. Jokes and Their Relation to the Unconscious. New York \& London: Norton.

Foucault, Michel 1978 [1976]. The History of Sexuality. Vol. 1. New York: Pantheon Books.

Grzybek, Peter 2000. Juznoslovenski erotski folklor: Zapazanja o narodnoj erotskoj frazelologii iz Dalmacije. [South Slav Erotic Folklore: Observations on Folk Erotic Phraseology from Dalmatia.] In: D. Ajdačić (ed.) Erotsko u folkloru Slovena: Zbornik radova. [The Erotic in the Folklore of the Slavs.] Belgrade: Stubovi kulture, pp. 295-325.

Gura, Aleksandr V. 2005. Coitus in the Symbolic Language of Slavic Culture. Folklore: Electronic Journal of Folklore, Vol. 30, pp. 135-154. http://dx.doi.org/10.7592/ FEJF2005.30.gura.

Hall, Stuart 1980. Encoding/Decoding. In: Stuart Hall \& Dorothy Hobson \& Andrew Lowe \& Paul Willis (eds.) Culture, Media, Language: Working Papers in Cultural Studies, 1972-79. London: Hutchinson, pp. 128-138. https://doi.org/10.1075/ z.184.211hal. 
Karadžić, Vuk Stefanović 1979. Crven ban: erotske narodne pesme. [The Red "Ban": Erotic Folk Songs.] Beograd: Prosveta.

Karanović, Zoja \& Jokić, Jasmina 2009. Smehovno i erotsko u srpskoj narodnoj kulturi $i$ poeziji. [Funny and Erotic in the Serbian Folk Culture and Poetry.] Novi Sad: Filozofski fakultet.

Kline, Paul 1977. The Psychoanalytic Theory of Humour and Laughter. In: Anthony J. Chapman \& Hugh C. Foot (eds.) It's a Funny Thing, Humour. Oxford: Pergamon Press, pp. 7-12.

Kostić, Aleksandar 1978. Seksualno u našoj narodnoj poeziji. [The Sexual in Our Folk Poetry.] Beograd \& Zagreb: Medicinska knjiga.

Krauss, Friedrich S. et al. (eds.) 1883. Kryptadia: Recueil de documents pour servir à l'étude des traditions populaires. Vol. 1. Heilbronn: Henninger Freres. Available at http://www.horntip.com/html/books_\%26_MSS/1880s/1883-1912_kryptadia_ (HCs)/index.htm, last accessed on 8 March 2019.

Krauss, Friedrich S. 1904-1913. Antropophyteia: Jahrbuch für folkloristische Erhebungen und Forschungen. Vol. 1-9. Available at http://www.horntip.com/ html/books_\%26_MSS/1900s/1904-1922_anthropophyteia_(HCs)/index.htm, last accessed on 8 March 2019.

Krstanović, Zdravko 1984. Erotske narodne pjesme. [Erotic Folk Poems.] Split: Vlastito izdanje.

Legman, Gershon 1962. Misconceptions in Erotic Folklore. The Journal of American Folklore, Vol. 75, No. 297, pp. 200-208. http://dx.doi.org/10.2307/537722.

Legman, Gershon 1968. Rationale of the Dirty Joke: An Analysis of Sexual Humor. New York: Grove Press.

Levine, Jacob \& Redlich, Fredrick C. 1955. Failure to Understand Humor. The Psychoanalytic Quarterly, Vol. 24, No. 4, pp. 560-572. http://dx.doi.org/10.1080/21674 086.1955.11926004.

Lövkrona, Inger 1998. Erotic Narrative and the Construction of Gender in Premodern Sweden. Journal of Folklore Research, Vol. 35, No. 2, pp. 145-156. Available at https://www.jstor.org/stable/3814753, last accessed on 4 March 2019.

Malinowski, Bronislaw 1926. Myth in Primitive Psychology. New York: Norton.

Martinoska, Ana 2007. Goliot na gosti: Antologija na makedonskiot erotski folklor. [The Naked Guest: An Anthology of Macedonian Erotic Folklore.] Skopje: Mi-An.

Miceva, Evgenija 2000. Erotski folklor i njegovi nosioci. [Erotic Folklore and Its Bearers.] In: D. Ajdačić (ed.) Erotsko u folkloru Slovena: Zbornik radova. [The Erotic in the Folklore of the Slavs.] Belgrade: Stubovi kulture, pp. 465-473.

Mrduljaš, Igor 1980. Kudilja i vreteno: Erotske narodne pjesme. [Whirl and Spindle: Erotic Folk Songs.] Zagreb: Znanje.

Oring, Elliot 1977. Rationale of the Dirty Joke: An Analysis of Sexual Humor. First Series by G. Legman; Rationale of the Dirty Joke: An Analysis of Sexual Humor. Second Series by G. Legman. Review. Western Folklore, Vol. 36, No. 4, pp. 365-371. DOI: $10.2307 / 1499200$.

Pandurević, Jelenka 2016. Folklorni Erotikon izmetsu Obredne i Poetske Metafore. [The Folklore Eroticon between the Ritual and Poetic Metaphor.] Knjizevna istorija / Literary History, Vol. 48, No. 159, pp. 9-36. Available at https://dialnet.unirioja. es/servlet/articulo?codigo $=6028999$, last accessed on 4 March 2019. 
Penushliski, Kiril 1989. Makedonski erotski prikazni. [Macedonian Erotic Tales.] Skopje: Misla.

Pilichkova, Sevim 2009. Erotski elementi vo turskoto narodno tvoreštvo od Republika Makedonija. [Erotic Elements in the Turkish Folklore in Macedonia.] Skopje: Institut za folklor "Marko Cepenkov".

Radcliffe-Brown, Alfred R. 1952. Structure and Function in Primitive Society: Essays and Addresses. Glencoe, Illinois: The Free Press. Available at https://archive.org/ details/structurefunctio00radc, last accessed on 26 February 2019.

Reichenbach, Anke 2015. Laughter in Times of Uncertainty: Negotiating Gender and Social Distance in Bahraini Women's Humorous Talk. Humor, Vol. 28, No. 4, pp. 511-539. http://dx.doi.org/10.1515/humor-2015-0098.

Risteski, Dragan 1994. Makedonski erotski pesni. [Macedonian Erotic Poems.] Skopje: Studenstski zbor.

Ruch, Willibald \& Köhler, Gabriele 1998. A Temperament Approach to Humor. In: Willibald Ruch (ed.) The Sense of Humor: Explorations of a Personality Characteristic. Berlin: Walter de Gruyter, pp. 203-228. https://doi.org/10.1515/9783110804607-011.

Scott, James C. 1990. Domination and the Arts of Resistance: Hidden Transcripts. Yale: Yale University Press.

Sikimić, Biljana 2013. How to Read Riddles: Erotic World of Cultural Plants. In: Zoja Karanović \& Jasmina Jokić (eds.) Plants and Herbs in Traditional Serbian Culture: Handbook of Folk Botany. Novi Sad: Faculty of Philosophy, pp. 71-84. Available at http://www.academia.edu/4873314, last accessed on 4 March 2019.

Sikimić, Biljana \& Otašević, Dorde 2000. Erotske narodne brzalice. [Erotic Folk Tongue Twisters.] In: D. Ajdačić (ed.) Erotsko u folkloru Slovena: Zbornik radova. [The Erotic in the Folklore of the Slavs.] Belgrade: Stubovi kulture, pp. 262-286. Available at http://www.academia.edu/3739665/, last accessed on 26 February 2019.

Sims, Martha C. \& Stephens, Martine 2005. Living Folklore: An Introduction to the Study of People and Their Traditions. Logan, Utah: Utah State University Press.

Smilevski, Nikifor 1993. Veleshki mrsni pesni. [Greasy Poems from Veles.] Veles: Radio 2000 .

Stanoev, Stanoj 2000. Seksualni vic, po materijalima iz bugarskog folklora. [Sexual Jokes According to the Bulgarian Folklore Material.] In: D. Ajdačić (ed.) Erotsko u folklore Slovena: Zbornik radova. [The Erotic in the Folklore of the Slavs.] Belgrade: Stubovi kulture, pp. 507-527.

Terseglav, Marko 1981. Klincek lesnikov. [Hazelnut Spike.] Ljubljana: Cankarjeva založba.

Velichkovski, Bone 1989. Makedonski erotski narodni pesni: Sekoj Petok urda jadam. [Macedonian Erotic Folk Poems: Each Friday I Eat Curds.] Kumanovo: Prosveta.

Vujkov, Balint 1990. Mrsne pripovitke: antologija bunjevačke erotske priče. [Greasy Stories.] Subotica: Osvit.

\section{INTERNET SOURCES}

http://www.pelister.org/folklore/erotic_folktales/index.html, last accessed on 25 February 2019.

www.vicoteka.mk, last accessed on 25 February 2019. 